\title{
事象関連電位(CNV)を用いたメンタル・ ストレスの評価研究
}

\author{
山本栄 (獨協大学経済学部経営学科)
}

A Study of the evaluation for mental stress with $\operatorname{ERP}(\mathrm{CNV})$

Sakae Yamamoto ( Dokkyo Univ. Dept. of Management Science)

\section{1.はじめに}

長時間OA機器を使うとストレスを強く感じる という作業者の訴えが多いといわれている。これ まではストレスに対し主観的なアンケート調査が 主流であったが、客観的で定量的把握が求められ ている。客観的方法としては生理的計測があり、 特に精神活動との関連から脳波の検討が考えられ る。本研究では誘発電位を基にOA機器作業と作 業ストレスの関係を明らかにすることを目的とし ている。

誘発電位の中でも事象関連電位のCNVを基にし た。この理由はOA機器を使うということは作業 者が情報処理を連続的に行なうという特徴があり、 このことがストレスに大きく関連すると考えた。

\section{2. 実鈋方法}

\section{2. $1 C N \vee$ 测定}

測定機器は日本光電ニューロパックミニー 4 で、 刺激条件は、第 1 刺激 S 1 (警告刺激) と第 2 刺激 S 2 (命令刺激) の刺激を一定の間隔で一 対呈示する。S 2 が呈示されたら、できるだけす ばやく応答するよう行動させた時、このS $1 \sim \mathrm{S} 2$ の刺激間隔に出現する緩かな陰性変動 $(\mathrm{C} \mathrm{N} \mathrm{V})$ を測定する。S 1 は音刺激で $80 \mathrm{~d} \mathrm{B、3} \mathrm{K} \mathrm{H}$ の純音を $1 \mathrm{~m} \mathrm{~s}$ 聞かせた。S 2 刺激は光によるフ ラッシュ刺激で $10 \mathrm{H} \mathrm{z}$ のフラッシュレイトであ る。S 1 とS 2 の間隔は $2 \mathrm{~s}$ である。加算回数は 35 回とし、アンプの条件はlow-cut $0.03 \mathrm{~Hz}$, Hi-cut $20 \mathrm{~Hz}$ で行なった。

\section{2 . 2 测定部位}

$\mathrm{F} \mathrm{z、C} z 、 P z$ とし、基準電極は左右両耳架 で採り、これらを共通化した。

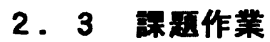

課題作業はワープロ作業とし、対照作業として 本を読ませた。

\section{4 被涂者}

被験者は男子 7 人、女子 3 人の計 10 人で行っ た。この内男子 5 名は対照作業も課した。

\section{3. 结果及ひ検封}

実験結果の例が図 1 に示してある。この図の上 段が実験前（ブレ）で、下段が実験後（ポスト） である。維軸は電位を表しており、単位は一目盛 り $12.5 \mu \mathrm{V}$ である。通常脳波の記録の上での 約束ごととして上側が負（マイナス、ネガティブ） を表し、下方向が正（プラス）を表すことになっ ている。

また横軸は 1 目盛りが $0 ５$ 秒である。横軸の 三角形の印は第一刺激が出たところである。

第一刺激が出てから波形がゆっくりと上側に上 昇しているのがわかる。そしてあるところまで行 くと急に下がるのが観察される。この急激に下降 するところが第二刺激による反応である。

第一刺激前 0.5 秒の平均電位を基準線とし、この 基準線と第一から第二刺激までの波形で囲まれる 面積を求めてみた。この面積の測定結果を基に各 被験者の負側（ネガティブ電位）の面積ブレとボ ストの比較を対応のある差の検定で調べた。その 結果 $\mathrm{T} 0=2.51$ となり、 $\mathrm{t}(9 、 5 \%)=$ 2.262だから負の面積では、ブレとポストに有意な 差が出ている事がわかる。さらにプレーポストが ほとんど正であることからも、ポストの方が面積 が小さくなっていることがわかる。また正の面積 では T $0=-1.31$ で以上の事より正の面積で は、差がないことがいえた。 

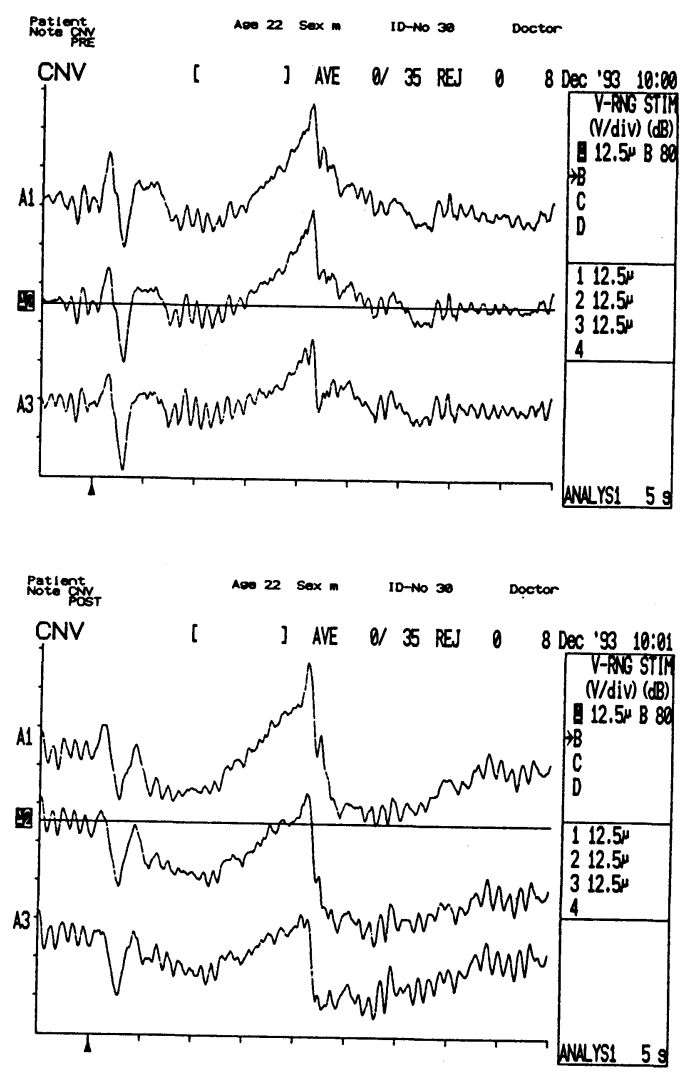

図1.CNVの実験前後の比較波形図

ところが対照作業結果では負側の面積は T $0=$ -0. 42 となり $\mathrm{t}(4,5 \%)=2.776$ で有意差 は認められない。同様に正側の面積は T 0 が

1.98で、これも有意差は認められなかった。 このCNVでは第 1 刺激 S 1 (警告刺激) と第 2 刺激 S 2 (命令刺激) の 2 つの感覚刺激を一 定の間隔で一対呈示し、S 2 が呈示されたら、で きるだけすばやく応答するようさせている。この S 1 S 2 の刺激間隔に出現する緩かなCNVとい う陰性変動が出現した。CNVは連続して与えら れた 2 つ事象にたいして前もって指示されてい る課題を行おうとして、被験者がその事象に注意 を向けたときに現れてくる大脳皮質の電位であり、 被験者の環境に対する受け止め方を表していると いわれている。

W a 1 t e r らによると、2つの刺激における 蓋然性をもった連合が重要であり、すなわち第 2
刺激に対する期待 ( “e x p e c t a n c y”) がそこに関与すると考え、 e x p e c t a n c y wave（E-wave）ともよんだ。その後、 C N Vの成立にあずかる要因として、さらに "motivation" , "attention", "cognition" などがあげられている。 また神経質な性格の人は、強いストレス下で誘発 電位が減少するということは良く知られている。 これらの先行研究と今回の結果より、ワープロ課 題作業はかなり精神的な負荷、すなわちストレス を反映していると考えられる。これに対し本を読 む課題ではCNVで差がでなかったことからも、ス トレスの負担に関する違いが現われたと考えてよ いであろう。

\section{4.まとめ}

V D T作業においてストレスの影響がCNVのネ ガティブ成分の減少傾向として見られた。C N V をストレスの計測指標と考えていく方向性が確か められたと考えられる。

今後さらにこの点を研究し、視覚誘発電位との 関連も検討し、評価を試みたい。

本研究は「第 20 回三越医学賞」の助成を受けま した。また産業医科大学松岡成明名誉教授に色々 御助言をいただきました。ここに謝意を表します。

\section{奎考文献}

- 下河内 稔「事象関連電位」

臨床脳波 Vol.23 No.10-12 1981 